\title{
Field evaluation of horticultural mineral oils and botanicals against bean thrips, Megalurothrips distalis (Karny) (Thysanoptera: Thripidae), in summer mung bean
}

Harkamalpreet Singh ${ }^{1}$, Harpreet Kaur Cheema ${ }^{2^{*}}$ (D) and Ravinder Singh ${ }^{2}$

\begin{abstract}
Background: Bean thrips, Megalurothrips distalis (Karny), are a serious insect pest of mung bean grown in summer season as a catch crop in wheat-rice cropping system in North West India. Severe incidence leads to flower shedding and fewer pods leading to loss in grain yield. Field studies were conducted to evaluate the efficacy of horticultural mineral oils, neem-based botanicals, and pongamia soap in the form of spray in comparison to the insecticide dimethoate in 2018 and 2019.

Main body: Randomized complete block design (RCBD) was used with 11 treatments including untreated control in 3 replications. Neem seed kernel extract (NSKE) at 5\% gave the highest mean percent reduction in the number of thrips (90.44 and 79.59\%), followed by $10 \mathrm{ml} \mathrm{I}^{-1}$ of Neem Kavach 1500 ppm (85.55 and 78.97\%) and the insecticide dimethoate 30\% EC at $250 \mathrm{ml} \mathrm{ha}^{-1}$ (84.92 and 78.22\%) 1 and 3 days after treatment. Neem Baan 1500 ppm, Indo-Neem 1500 ppm, and Nimbecidine 300 ppm each at $10 \mathrm{ml} \mathrm{I}^{-1}$ also provided $75.29-82.42 \%$ and $61.18-$ 75.82\% reduction 1 and 3 days after treatment. Horticultural mineral oils also reduced the insect population by about 64\%, while pongamia soap was least effective (31.58\%) among botanicals. Dimethoate $30 \% \mathrm{EC}$ at $250 \mathrm{ml} \mathrm{ha}^{-1}$ recorded the highest grain yield and net returns, followed by NSKE, Nimbecidine, and Neem Kavach that were on par with it. Homemade neem extracts evaluated in 2019 caused 62.7-77.3\% reduction in thrips population up to 3 days after treatment with yields comparable to $10 \mathrm{mll}^{-1}$ of Indo-Neem spray.
\end{abstract}

Conclusion: The study indicated that neem extract was capable to manage the bean thrips in flowers of summer mung bean and obtained a high grain yield.

Keywords: Botanicals, Neem, Mineral oils, Bean thrips, Megalurothrips distalis, Mung bean

\section{Background}

Mung bean, Vigna radiata (L.) Wilczek, is also known as a warm season grain legume crop. It has great importance in the vegetarian diet and is used as cereal supplement for human diets due to its high lysine content.

\footnotetext{
*Correspondence: hkcheema@pau.edu

2Department of Plant Breeding and Genetics, Punjab Agricultural University, Ludhiana, Punjab 141004, India

Full list of author information is available at the end of the article
}

Mung bean seeds are rich source of minerals and protein (Dahiya et al. 2013). Its immature grains are used as a vegetable and are the source of plant protein, fiber, antioxidants, and phytonutrients which provide numerous health benefits. Mung bean is an economically important crop of Asia, especially in the Indian sub-continent grown globally on an area of $5.5 \mathrm{M}$ ha (Weinberger 2003). India is the primary producer as well as consumer 
of mung bean, contributing $65 \%$ of global crop production (Vijayalakshmi et al. 2003).

Mung bean yield is affected by several biotic and abiotic factors, of which insect pests are of much importance. Among its various insect pests, whitefly Bemisia tabaci (Gennadius), jassid, Empoasca spp., and bean thrips, Megalurothrips distalis (Karny), are the major sucking pests (Kooner et al. 2006). Whitefly and jassid cause damage mainly in the kharif or the rainy season crop. Verma et al. (1980) reported 3 species of thrips on summer mung bean in India, viz., Frankliniella schultzei (Trybom), Thrips flavus Schrank, and Megalurothrips distalis (Karny). Among these species, M. distalis is the most important thrips found in flowers of summer mung bean crop. Both nymphs and adults suck the oozing plant cell sap causing flower shedding before opening resulting in elongation of terminal shoot. Under severe incidence, the plants become bushy, dark green with few pods leading to loss in grain yield (Kooner et al. 1983). It is imperative to control $M$. distalis damages to minimize attributed yield losses. Chhabra and Kooner (1985a) reported the cumulative damage caused by insect pest complex (Melanagromyza phaseoli, Acherontia styx, and $M$. distalis) as up to $54.3 \%$ in mung bean.

Some bio-rational management strategies such as botanical-based insecticides or biopesticides that are economically and environmentally safe to non-target organisms and humans are desirable for managing insect pests (Begum et al. 2013). Botanicals such as neem (Azadirachta indica Juss.) and Karanj (Pongamia glabra) can be effectively used in managing pests in field crops and stored grains (Regnault-Roger and Philogène 2008). A. indica is a well-known plant species that has insecticidal activities against more than 250 species of agricultural pests (Morgan 2009). Seeds of neem comprise $40 \%$ oil with azadirachtin as the major active ingredient having insecticidal property (Isman et al. 1991). Petroleum spray oils and mineral oils have been used also for controlling insect pests in many crops around the world (Mensah et al. 2005a, 2005b; Najar-Rodriguez et al. 2007). To overcome any negative effects resulting from use of synthetic insecticides, the study was conducted to test the efficacy of alternate strategies such as botanicals and horticultural mineral oils (HMOs) against bean thrips in mung bean.

\section{Materials and methods}

\section{Neem seed kernel extraction}

Dried neem seed kernels were procured from the local market of Ludhiana and powdered in electric grinder. The powdered kernels were soaked overnight in water and filtered next day for spraying as a $5 \%$ neem seed kernel extract (NSKE). Commercial formulations of neem (Neem Baan 1500 ppm, Indo-Neem 1500 ppm, Nimbecidine 300 ppm, Neem Kavach 1500 ppm) and the insecticide Rogor
$30 \%$ EC (dimethoate 30\% EC) were procured from the local market. The 4 commercial formulations of neem were applied at the rate of $10 \mathrm{ml} \mathrm{l}^{-1}$, using $200 \mathrm{~L}$ of water per ha. Pongamia soap (Pongamia pinnata) was procured from the Indian Institute of Horticultural Research, Bangalore, and was applied at $10 \mathrm{gl}^{-1}$. MAK All Season HMO was procured from Bharat Petroleum Corporation Ltd. Mumbai, while Arbofine HMO was obtained from Total Oil India Pvt. Ltd., Mumbai. Homemade neem extracts were evaluated only in 2019. These were prepared by boiling for half an hour or simply by overnight soaking of $1 \mathrm{~kg}$ of Neem leaves and fruits in $2 \mathrm{~L}$ of water. The contents were filtered and used at the rate of $10 \mathrm{mll}^{-1}$ of water. Rogor 30\% EC (dimethoate 30\% EC) was applied at the rate of $250 \mathrm{ml} \mathrm{ha}^{-1}$ ( $75 \mathrm{~g}$ a.i. per ha using $200 \mathrm{~L}$ of water) as a standard recommended insecticide against thrips in summer mung bean (Anonymous 2017). Water spray at $200 \mathrm{~L}$ per ha was also evaluated, while untreated plots served as control.

\section{Phytotoxicity of horticultural mineral oil}

Phytotoxicity of HMOs (Arbofine HMO and MAK All Season HMO) was assessed at concentrations ranging from 0.10 to $0.75 \%$ by spraying on 20 days old summer mung bean crop. Both the HMOs exhibited yellowing of leaf lamina at concentrations higher than $0.3 \%$, whereas treatment at $0.3 \%$ concentration was non-phytotoxic and suitable for the crop.

\section{Experimental design}

Experiments were carried out to determine the efficacy of field applications of horticultural mineral oils and botanicals for the management of $M$. distalis in summer mung bean at Ludhiana $\left(30.9010^{\circ} \mathrm{N}, 75.8573^{\circ} \mathrm{E}\right)$. An early maturing variety of summer mung bean (TMB 37) was sown as per recommended agronomic practices at Pulses Research Farm, Department of Plant Breeding and Genetics, Punjab Agricultural University, Ludhiana, in plots measuring $10.5 \mathrm{~m}^{2}$ (9 rows of $5 \mathrm{~m}$ row length with $22.5 \mathrm{~cm}$ spacing) in 3 replications, using the randomized complete block design (RCBD). The crop was monitored regularly for natural appearance of thrips. Except bean thrips, no other insect pests were observed on the crop. Foliar sprays of HMOs, neem-based commercial formulations, NSKE, homemade neem extract, pongamia, and dimethoate 30\% EC were sprayed, using backpack sprayer in the plots upon appearance of bean thrips at flowering initiation stage of the crop. Numbers of thrips (nymphs and adults) were recorded from 10 randomly selected flowers from each plot before treatment and 1, 3, 7, and 10 days after treatment (DAT). The effect of treatments on mung bean grain yield was recorded, and economic returns were estimated. 


\section{Statistical analysis}

Data obtained were transformed to square root values and then subjected to analysis of variance (ANOVA) using a randomized complete block design (RCBD). The means were separated using least significant difference (LSD) at $5 \%$ level of significance (Gomez and Gomez 1984). The reduction percentage was calculated according to Henderson and Tilton (1955) with the following equation:

$100 \times 1$ - (Number of insects in control before spray $x$ Number of insects in treatment after spray/ Numberof insects in control after spray $x$ Number of insects in treatment before spray)

The cost of treatment was estimated based on retail price of insecticides. Net profit was estimated based on the income of grain yield (Indian Rupees INR 70 per $\mathrm{kg}$ ) and the cost per hectare from treatments.

\section{Results and discussion}

\section{Average numbers of $M$. distalis after treatment}

In 2018, the numbers of thrips per 10 flowers did not differ significantly and ranged from $5.67-10.00$ before treatment (Table 1). Following application of 5\% NSKE, 250 $\mathrm{ml} \mathrm{ha}^{-1}$ of dimethoate $30 \% \mathrm{EC}, 10 \mathrm{mll}^{-1}$ of Indo-Neem $1500 \mathrm{ppm}, 10 \mathrm{ml} \mathrm{l}^{-1}$ of Nimbecidine $300 \mathrm{ppm}, 10 \mathrm{mll}^{-1}$ of Neem Kavach 1500 ppm, 0.3\% Arbofine HMO, $10 \mathrm{ml} \mathrm{l}^{-1}$ of Neem Baan $1500 \mathrm{ppm}, 10 \mathrm{gl}^{-1}$ of Pongamia soap, and 0.3\% MAK All Season HMO, the thrips count was lowered to $0.67,1.33,1.33,2.00,2.33,2.33,3.00,3.33$, and 4.00 thrips per 10 flowers, respectively 1 day after treatment (DAT). However, in case of water spray (control), thrips incidence reduced from 6.67 to 3.33 , one DAT, and then increased soon after (3 DAT) to 8.67 and to 14.00 thrips per 10 flowers up to $10 \mathrm{DAT}$, while in untreated control, there was a continuous increase in incidence on all the days of observation. One day after spray, 5\% NSKE was found to be the most effective against bean thrips ( 0.67 thrips per 10 flowers) and treatments with dimethoate, Indo-Neem, Nimbecidine, Neem Kavach, and Arbofine HMO were on par with it $(P=0.05)$.

Similar trend was observed in 2019, where the thrips count per 10 flowers ranged from 10.33-15.33 in various plots before treatment; the differences were nonsignificant (Table 2). One DAT, the thrips counts per 10 flowers were reduced in all the treatments, except the water spray and untreated control. Least numbers of thrips (1.33 thrips per 10 flowers) were observed in the treatments 5\% NSKE and $10 \mathrm{ml} \mathrm{l}^{-1}$ of Neem Kavach 1500 ppm, followed by insecticide dimethoate and Arbofine HMO (2.00 thrips/10 flowers). Three DAT, Neem Kavach had the least insect incidence, followed by $250 \mathrm{ml} \mathrm{ha}^{-1}$ dimethoate 30\% EC, 5\% NSKE, Indo-Neem, Neem Baan, and Arbofine HMO, which were statistically on par with it and significantly better than remaining treatments. Incidence of thrips in homemade neem extracts ranged from 3.33-5.33 and 5.33-6.66 thrips per 10 flowers one and 3 DAT, respectively as compared to 15.33 and 19.33 ones in untreated control in 2019 (Table 2).

Pooled data, reflected lower incidence of thrips, was observed 1 DAT at the treatments 5\% NSKE (1.00 thrips/10 flowers), followed by dimethoate $30 \%$ EC, Neem Kavach, Indo-Neem, Arbofine HMO, and Nimbecidine, which were on par with it (Table 3). The least effective treatments were MAK All season HMO (5.50) and pongamia

Table 1 Efficacy of mineral oils and botanicals on the incidence of Megalurothrips distalis in summer mung bean in 2018

\begin{tabular}{|c|c|c|c|c|c|}
\hline \multirow[t]{2}{*}{ Treatment } & \multicolumn{5}{|c|}{ No. of thrips per 10 flowers } \\
\hline & Pre treatment & 1DAT & 3DAT & 7DAT & 10DAT \\
\hline MAK All Season HMO 0.3\% & 10.00 & $4.00^{c}(2.22)$ & $5.00^{\mathrm{cd}}(2.44)$ & $7.33^{\text {de }}(2.89)$ & $10.33^{a}(3.36)$ \\
\hline Arbofine $\mathrm{HMO}$ 0.3\% & 7.00 & $2.33^{\mathrm{abc}}(1.80)$ & $4.67^{\mathrm{cd}}(2.38)$ & $5.00^{\mathrm{abc}}(2.44)$ & $9.00^{\mathrm{a}}(3.16)$ \\
\hline NSKE 5\% & 5.67 & $0.67^{\mathrm{a}}(1.27)$ & $2.00^{\mathrm{a}}(1.72)$ & $4.67^{\mathrm{ab}}(2.38)$ & $7.67^{\mathrm{a}}(2.94)$ \\
\hline Neem Baan 1500 ppm 10 ml I & 9.00 & $3.00^{\mathrm{bc}}(1.96)$ & $4.33^{\mathrm{cd}}(2.31)$ & $6.33^{\text {bcde }}(2.71)$ & $9.00^{\mathrm{a}}(3.15)$ \\
\hline Indo-Neem 1500 ppm $10 \mathrm{ml} \mathrm{I}^{-1}$ & 8.00 & $1.33^{\mathrm{ab}}(1.52)$ & $4.67^{\mathrm{cd}}(2.38)$ & $6.00^{\mathrm{abcd}}(2.63)$ & $8.67^{a}(3.11)$ \\
\hline Nimbecidine 300 ppm $10 \mathrm{ml} \mathrm{l}^{-1}$ & 9.00 & $2.00^{\mathrm{abc}}(1.72)$ & $4.33^{\mathrm{cd}}(2.29)$ & $6.67^{\text {cde }}(2.76)$ & $9.00^{\mathrm{a}}(3.14)$ \\
\hline Neem Kavach 1500 ppm 10 ml I & 9.00 & $2.33^{\mathrm{abc}}(1.80)$ & $4.00^{\mathrm{bc}}(2.23)$ & $7.00^{\text {de }}(2.82)$ & $8.67^{\mathrm{a}}(3.09)$ \\
\hline Pongamia soap $10 \mathrm{gl}^{-1}$ & 6.00 & $3.33\left(2.07^{\mathrm{C}}\right)$ & $5.67\left(2.57^{d}\right)$ & $8.00\left(3.00^{\mathrm{ef}}\right)$ & $10.67\left(3.40^{\mathrm{ab}}\right)$ \\
\hline Rogor 30\% EC (dimethoate 30\% EC) $250 \mathrm{ml} \mathrm{ha}^{-1}$ & 8.00 & $1.33^{\mathrm{ab}}(1.47)$ & $2.67^{\mathrm{ab}}(1.90)$ & $4.33^{\mathrm{a}}(2.31)$ & $8.67^{\mathrm{a}}(3.10)$ \\
\hline Water & 6.67 & $3.33^{\mathrm{C}}(2.07)$ & $8.67^{e}(3.10)$ & $10.00^{f}(3.31)$ & $14.00^{b c}(3.87)$ \\
\hline Untreated control & 9.00 & $10.00^{d}(3.31)$ & $12.33^{f}(3.65)$ & $14.67^{9}(3.95)$ & $17.33^{\mathrm{C}}(4.27)$ \\
\hline $\mathrm{CD}(P=0.05)$ & NS & $(0.53)$ & $(0.34)$ & $(0.34)$ & $(0.50)$ \\
\hline$F$ value; $d f=10$ & 1.77 & 9.23 & 21.73 & 16.93 & 5.46 \\
\hline
\end{tabular}

Means followed by the same letter in each column with treatments did not differ significantly at the $5 \%$ level by LSD test. Figures in parentheses are $\sqrt{ } \mathrm{n}+1$ transformed values

DAT days after treatment 
Table 2 Efficacy of mineral oils and botanicals on the incidence of Megalurothrips distalis in summer mung bean in 2019

\begin{tabular}{|c|c|c|c|c|c|}
\hline \multirow[t]{2}{*}{ Treatment } & \multicolumn{5}{|c|}{ No. of thrips per 10 flowers } \\
\hline & Pre treatment & 1 DAT & 3 DAT & 7 DAT & 10 DAT \\
\hline MAK All Season HMO & 14.67 & $7.00^{c}(2.82)$ & $7.00^{\mathrm{b}}(2.82)$ & $12.00^{d}(3.60)$ & $13.33^{\mathrm{abcd}}(3.78)$ \\
\hline Arbofine HMO & 10.67 & $2.00^{\mathrm{ab}}(1.72)$ & $4.00^{\mathrm{a}}(2.20)$ & $10.67^{\text {bcd }}(3.41)$ & $14.00^{\text {bcde }}(3.87)$ \\
\hline NSKE & 13.33 & $1.33^{\mathrm{a}}(1.47)$ & $3.33^{\mathrm{a}}(2.07)$ & $8.67^{\mathrm{ab}}(3.11)$ & $10.00^{\mathrm{a}}(3.30)$ \\
\hline Neem Baan & 14.00 & $3.33^{\mathrm{b}}(2.07)$ & $3.33^{\mathrm{a}}(2.07)$ & $10.00^{\mathrm{bcd}}(3.31)$ & $12.00^{\mathrm{abc}}(3.60)$ \\
\hline Indo-Neem & 12.67 & $2.67^{\mathrm{ab}}(1.90)$ & $3.33^{\mathrm{a}}(2.07)$ & $10.00^{\mathrm{bcd}}(3.31)$ & $12.00^{\mathrm{abc}}(3.60)$ \\
\hline Nimbecidine & 10.33 & $2.67^{\mathrm{ab}}(1.90)$ & $6.00^{\mathrm{b}}(2.65)$ & $11.33^{\mathrm{cd}}(3.51)$ & $12.67^{f}(3.67)$ \\
\hline Neem Kavach & 14.00 & $1.33^{\mathrm{a}}(1.47)$ & $2.67^{\mathrm{a}}(1.90)$ & $7.33^{\mathrm{a}}(2.88)$ & $10.87^{\mathrm{ab}}(3.41)$ \\
\hline Pongamia soap & 11.33 & $7.33\left(2.88^{\mathrm{C}}\right)$ & $10.67\left(3.41^{\mathrm{C}}\right)$ & $16.00\left(4.12^{\mathrm{e}}\right)$ & $14.67^{\text {cde }}(3.96)$ \\
\hline Dimethoate 30\% EC & 12.00 & $2.00^{\mathrm{ab}}(1.72)$ & $3.33^{\mathrm{a}}(2.07)$ & $9.00^{\mathrm{abc}}(3.16)$ & $13.33^{\mathrm{abcd}}(3.78)$ \\
\hline Homemade neem extract (boiled) & 13.33 & $3.33^{b}(2.08)$ & $5.33^{\mathrm{b}}(2.51)$ & $11.33^{\mathrm{cd}}(3.51)$ & $13.33^{\mathrm{abcd}}(3.78)$ \\
\hline Homemade neem extract (overnight soaking) & 12.66 & $5.33^{b c}(2.51)$ & $6.66^{\mathrm{b}}(2.76)$ & $12.00^{d}(3.58)$ & $14.66^{\text {cde }}(3.95)$ \\
\hline Water & 15.33 & $12.00^{d}(3.60)$ & $14.67^{d}(3.95)$ & $16.67^{\mathrm{e}}(4.19)$ & $18.00^{\mathrm{e}}(4.35)$ \\
\hline Untreated control & 14.00 & $15.33^{d}(4.03)$ & $19.33^{\mathrm{e}}(4.51)$ & $20.00^{f}(4.58)$ & $17.33^{\text {de }}(4.28)$ \\
\hline $\mathrm{CD}(P=0.05)$ & NS & $(0.57)$ & $(0.39)$ & $(0.38)$ & $(0.50)$ \\
\hline$F$ value; $d f=12$ & 0.87 & 17.42 & 36.74 & 14.52 & 3.09 \\
\hline
\end{tabular}

Means followed by the same letter in each column with treatments did not differ significantly at the $5 \%$ level by LSD test. Figures in parentheses are $\sqrt{ } n+1$ transformed values

DAT days after treatment

Table 3 Incidence of bean thrips, Megalurothrips distalis, and reduction percent after application of treatments in summer mung bean (pooled data of 2018 and 2019)

\begin{tabular}{|c|c|c|c|c|c|c|c|c|c|}
\hline \multirow[t]{2}{*}{ Treatment } & \multirow{2}{*}{$\begin{array}{l}\text { Pre } \\
\text { treatment } \\
\text { No. of thrips/ } \\
10 \text { flowers }\end{array}$} & \multicolumn{2}{|l|}{$1 \mathrm{DAT}$} & \multicolumn{2}{|l|}{3 DAT } & \multicolumn{2}{|l|}{7 DAT } & \multicolumn{2}{|l|}{10 DAT } \\
\hline & & $\begin{array}{l}\text { No. of thrips/ } \\
10 \text { flowers }\end{array}$ & $\begin{array}{l}\text { Reduction } \\
\%\end{array}$ & $\begin{array}{l}\text { No. of thrips } \\
/ 10 \text { flowers }\end{array}$ & $\begin{array}{l}\text { Reduction } \\
\%\end{array}$ & $\begin{array}{l}\text { No. of thrips/ } \\
10 \text { flowers }\end{array}$ & $\begin{array}{l}\text { Reduction } \\
\%\end{array}$ & $\begin{array}{l}\text { No. of thrips/ } \\
10 \text { flowers }\end{array}$ & $\begin{array}{l}\text { Reduction } \\
\%\end{array}$ \\
\hline $\begin{array}{l}\text { MAK All } \\
\text { Season } \\
\text { HMO }\end{array}$ & 12.33 & $5.50^{c}(2.52)$ & 59.47 & $6.00^{\text {de }}(2.63)$ & 64.67 & $9.67^{c}(3.24)$ & 47.95 & $11.83^{\mathrm{bc}}(3.57)$ & 36.34 \\
\hline $\begin{array}{l}\text { Arbofine } \\
\mathrm{HMO}\end{array}$ & 8.83 & $2.16^{\mathrm{ab}}(1.77)$ & 77.78 & $4.33^{\mathrm{bcd}}(2.30)$ & 64.39 & $7.83^{\mathrm{ab}}(2.93)$ & 41.16 & $11.50^{\mathrm{bc}}(3.51)$ & 13.58 \\
\hline NSKE & 9.50 & $1.00^{\mathrm{a}}(1.38)$ & 90.44 & $2.67^{\mathrm{a}}(1.89)$ & 79.59 & $6.67^{\mathrm{a}}(2.74)$ & 53.41 & $8.83^{\mathrm{a}}(3.13)$ & 38.33 \\
\hline Neem Baan & 11.50 & $3.16^{\mathrm{bc}}(2.02)$ & 75.29 & $3.83^{\mathrm{abc}}(2.19)$ & 75.82 & $8.17^{\mathrm{abc}}(3.00)$ & 52.86 & $10.50^{\mathrm{abc}}(3.38)$ & 39.42 \\
\hline Indo-Neem & 10.33 & $2.00^{\mathrm{ab}}(1.70)$ & 82.42 & $4.00^{\mathrm{abc}}(2.22)$ & 71.88 & $8.00^{\mathrm{abc}}(2.97)$ & 48.62 & $10.33^{\mathrm{ab}}(3.35)$ & 33.65 \\
\hline Nimbecidine & 9.67 & $2.33^{\mathrm{ab}}(1.81)$ & 78.12 & $5.17^{\mathrm{cd}}(2.47)$ & 61.18 & $9.00^{\mathrm{bc}}(3.13)$ & 38.25 & $10.83^{\mathrm{abc}}(3.41)$ & 25.69 \\
\hline $\begin{array}{l}\text { Neem } \\
\text { Kavach }\end{array}$ & 11.50 & $1.83^{\mathrm{ab}}(1.63)$ & 85.55 & $3.33^{\mathrm{ab}}(2.06)$ & 78.97 & $7.17^{\mathrm{a}}(2.85)$ & 58.63 & $9.67^{\mathrm{ab}}(3.25)$ & 44.21 \\
\hline $\begin{array}{l}\text { Pongamia } \\
\text { soap }\end{array}$ & 8.67 & $5.33^{\mathrm{cd}}(2.48)$ & 44.18 & $8.17^{\mathrm{e}}(2.99)$ & 31.58 & $12.00^{d}(3.56)$ & 8.16 & $12.67^{\complement}(3.68)$ & 3.04 \\
\hline $\begin{array}{l}\text { Dimethoate } \\
\text { 30\% EC }\end{array}$ & 10.00 & $1.66^{\mathrm{ab}}(1.60)$ & 84.92 & $3.00^{\mathrm{ab}}(1.98)$ & 78.22 & $6.67^{\mathrm{a}}(2.73)$ & 55.74 & $11.00^{\mathrm{abc}}(3.44)$ & 27.02 \\
\hline Water & 11.00 & $7.66^{d}(2.83)$ & 36.77 & $11.67^{f}(3.53)$ & 22.98 & $13.33^{d}(3.76)$ & 19.59 & $16.00^{d}(4.11)$ & 3.49 \\
\hline Control & 11.50 & $12.66^{\mathrm{e}}(3.68)$ & - & $15.83^{9}(4.07)$ & - & $17.33^{\mathrm{e}}(4.27)$ & - & $17.33^{d}(4.27)$ & - \\
\hline $\begin{array}{l}C D(P= \\
0.05)\end{array}$ & NS & $(0.46)$ & & $(0.37)$ & & $(0.28)$ & & $(0.33)$ & \\
\hline $\begin{array}{l}F \text { value; } \mathrm{df}= \\
12\end{array}$ & 0.79 & 17.46 & & 28.41 & & 23.94 & & 9.13 & \\
\hline
\end{tabular}

Means followed by the same letter in each column with treatments did not differ significantly at the $5 \%$ level by LSD test. Figures in parentheses are $\sqrt{ } \mathrm{n}+1$ transformed values 
soap (5.33 thrips per 10 flowers). Both 3 and 7 DAT, NSKE 5\% was found to be as effective as dimethoate $30 \%$ EC, followed by Neem Kavach.

\section{Reduction percentage}

One day after treatment, NSKE 5\% gave the highest mean percent reduction in the number of thrips (90.44\%), followed by Neem Kavach $(85.55 \%)$, dimethoate $30 \%$ EC (84.92\%), Indo-Neem (82.42\%), Nimbecidine (78.12\%), and Neem Baan (75.29\%) (Table 3). Arbofine HMO provided $77.78 \%$ reduction, while pongamia provided the least reduction of $44.18 \%$. In a similar trend, 3 DAT, NSKE 5\% gave the highest mean percent reduction in the number of thrips (79.59\%), followed by Neem Kavach (78.97\%), dimethoate 30\% EC (78.22\%), Neem Baan (75.82\%), Indo-Neem (71.88\%), and Nimbecidine (61.18\%). Horticultural mineral oils also reduced the insect population with about $64 \%$, while pongamia soap was the least effective (31.58\%). Maximum efficacy of all 5 neem-based treatments was obtained 1 DAT (75.29$90.44 \%$ reduction in thrips population) that became $61.18-79.59 \% 3$ DAT. The efficacy subsequently decreased to reach $38.25-58.63$ and $25.69-44.21 \%$ reduction after 7 and 10 days of spray, respectively. Although the efficacy of all treatments lessened over a period of 7-10 days, second spray was not considered as the crop has a short duration. In this hot dry summer season, the crop matures in 60 days and is a catch crop that fits well in the wheat-rice cropping system.

Neem extracts usually act as antifeedant, repellent, and oviposition deterrent on a wide spectrum of insect pests (Regnault-Roger and Philogène 2008). Neem seed kernel extract of $5 \%$ was found to be effective against flower bud thrips, Megalurothrips sjostedti Trybom, in cowpea in Nigeria (Egho and Emosairue 2010a). Irulandi and Balasubramanian (2000) reported that 5\% NSKE and 2\% neem oil were effective against $M$. distalis in mung bean in South India. Application of local neem oil proved most effective in reducing $M$. sjostedti population to a level similar to insecticides when applied at early stage (budding) than late stage (25\% flowering) in cowpea (Traore et al. 2019). This is in agreement with the present study, where neem-based treatments were effective against $M$. distalis when applied at flowering initiation stage. NSKE 5\% and neem oil has been reported to be highly effective against onion thrips (Singh et al. 2009) and cotton thrips (Asif et al. 2018). Kordy and Barakat (2014) reported that applications of Nimbecidine $^{\bullet}$ (azadirachtin), followed by Tracer ${ }^{\bullet}$ (spinosad), gave effective reduction in incidence of onion thrips after 7 days (94.64 and 93.65\%). In the present study, Nimbecidine reduced thrips to $61.18 \%, 3$ DAT. The soaked and boiled homemade neem extracts evaluated in 2019 recorded thrips reductions of 61.69 and $77.27 \%$, respectively, 1DAT; 62.00 and $71.05 \%$, respectively, 3DAT; 33.64 and $40.50 \%$, respectively, 7DAT; and only 6.55 and $19.30 \%$, respectively, $10 \mathrm{DAT}$ as can be derived from Table 2 according to Henderson and Tilton (1955). Overall, dimethoate was still the most effective treatment providing 55.74 to $84.92 \%$ reduction up to 7 DAT but with decreasing efficacy over the days as was the case for all the treatments. Earlier, Chhabra and Kooner (1985b) reported that dimethoate gave a high control of thrips in mung bean in Punjab. HMOs also reduced the insect population with $41.16-77.78 \%$, while pongamia soap was the least effective (8.16-44.18\%) among all botanicals although it was significantly better than water spray alone and untreated control.

Yield and percent increase in yield over untreated control In 2018, yield of mung bean ranged from 968 to $1430 \mathrm{~kg} \mathrm{ha}{ }^{-1}$ in various treatments, as compared to 963 and $914 \mathrm{~kg} \mathrm{ha}^{-1}$ in water spray and untreated control, respectively (Table 4). Among all treatments, significantly higher yield was recorded at dimethoate $30 \%$ EC $\left(1430 \mathrm{~kg} \mathrm{ha}^{-1}\right)$, and nimbecidine was on par with it. Among the botanicals and HMOs, Nimbecidine gave the highest grain yield $\left(1389 \mathrm{~kg} \mathrm{ha}^{-1}\right)$, followed by Neem Kavach, NSKE, and Indo-Neem which were on par with it. In 2019, grain yield was the highest at NSKE $\left(1302 \mathrm{~kg} \mathrm{ha}^{-1}\right)$, and the treatments dimethoate $\left(1245 \mathrm{~kg} \mathrm{ha}^{-1}\right)$ and Neem Kavach $\left(1236 \mathrm{~kg} \mathrm{ha}^{-1}\right)$ were on par with it.

Table 4 Yield of summer mung bean as influenced by various treatments for management of Megalurothrips distalis

\begin{tabular}{|c|c|c|c|c|}
\hline \multirow[t]{2}{*}{ Treatment } & \multicolumn{3}{|c|}{ Yield $\left(\mathrm{kg} \mathrm{ha}^{-1}\right)$} & \multirow{2}{*}{$\begin{array}{l}\text { Percent } \\
\text { increase } \\
\text { in yield } \\
\text { over } \\
\text { control }\end{array}$} \\
\hline & 2018 & 2019 & Mean & \\
\hline MAK All Season HMO & $1110^{d}$ & $865^{\text {de }}$ & $987^{e}$ & 14.50 \\
\hline Arbofine $\mathrm{HMO}$ & $1130^{d}$ & $1013^{c}$ & $1071^{d}$ & 24.25 \\
\hline NSKE & $1345^{b}$ & $1302^{a}$ & $1324^{a}$ & 53.59 \\
\hline Neem Baan & $1245^{c}$ & $1223^{b}$ & $1234^{c}$ & 43.16 \\
\hline Indo-Neem & $1343^{b}$ & $1189^{b}$ & $1266^{b c}$ & 46.86 \\
\hline Nimbecidine & $1389^{a b}$ & $1230^{b}$ & $1309^{a b}$ & 51.86 \\
\hline Neem Kavach & $1362^{b}$ & $1236^{a b}$ & $1299^{a b}$ & 50.69 \\
\hline Pongamia soap & $968^{\mathrm{e}}$ & $930^{d}$ & $949^{e}$ & 10.09 \\
\hline Dimethoate 30\% EC & $1430^{\mathrm{a}}$ & $1245^{a b}$ & $1337^{a}$ & 55.10 \\
\hline Water & $963^{\mathrm{e}}$ & $810^{e}$ & $887^{f}$ & 2.90 \\
\hline Control & $914^{\mathrm{e}}$ & $810^{e}$ & $862^{f}$ & - \\
\hline $\mathrm{CD}(P=0.05)$ & 54.46 & 70.97 & 57.79 & \\
\hline$F$ value; $\mathrm{df}=12$ & 106.4 & 64.66 & 86.17 & \\
\hline
\end{tabular}

Means followed by the same letter in each column with treatments did not differ significantly at the $5 \%$ level by LSD test. Yields obtained in 2019 in additional treatment homemade neem (boiled) $=1210 \mathrm{~kg} \mathrm{ha}^{-1}$ and overnight soaked $=1102 \mathrm{~kg} \mathrm{ha}^{-1}$ 


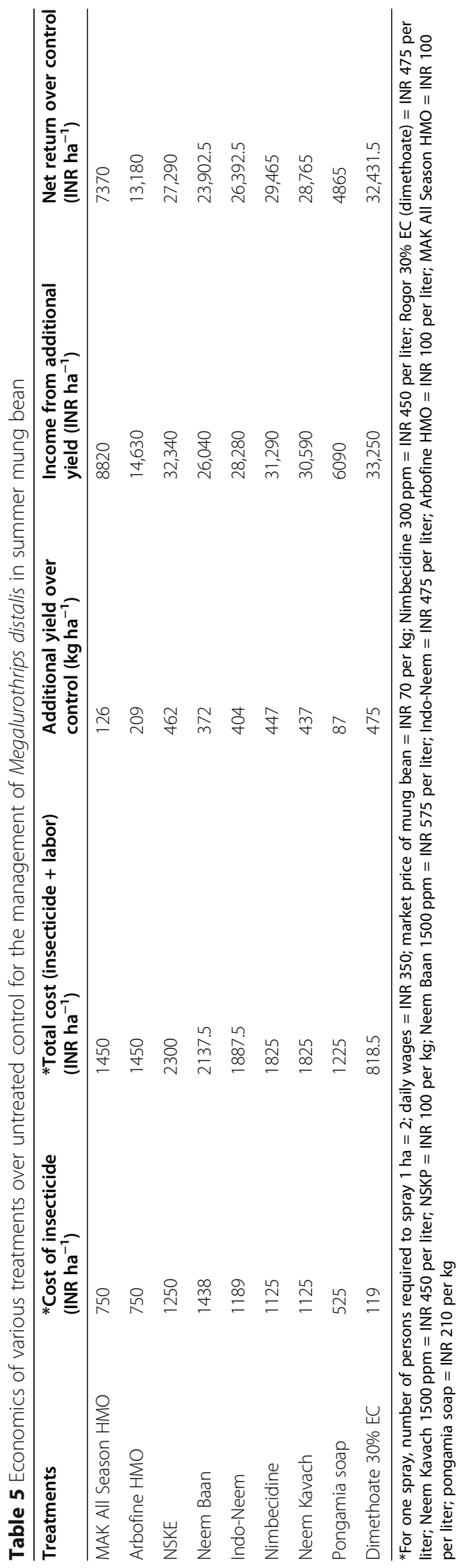


Mean yields in treatments dimethoate $30 \%$ EC $\left(1337 \mathrm{~kg} \mathrm{ha}^{-1}\right)$ and NSKE $\left(1324 \mathrm{~kg} \mathrm{ha}^{-1}\right)$ were significantly higher than other treatments, while the lowest mean grain yields were recorded in water spray and untreated control (887 and $862 \mathrm{~kg} \mathrm{ha}^{-1}$, respectively), followed by pongamia soap $\left(949 \mathrm{~kg} \mathrm{ha}^{-1}\right)$ and Arbofine HMO $\left(987 \mathrm{~kg} \mathrm{ha}^{-1}\right)$. The percent increase in yield over untreated control was 55.10, 53.59, 51.86, and $50.69 \%$, following application of dimethoate $30 \%$ EC, NSKE, Nimbecidine, and Neem Kavach, respectively. In 2019, treatment with homemade neem extracts (boiled and overnight soaking) resulted in a yield of 1210 and $1102 \mathrm{Kg} \mathrm{ha}^{-1}$, respectively, to get 40.37 and $27.9 \%$ increase in yield over untreated control. Chhabra and Kooner (1985b) reported that dimethoate gave a high control of thrips in mung bean at Ludhiana and increased the yield with up to $89 \%$. Horticultural mineral oils MAK All Season and Arbofine were less effective than botanicals as they led to only 14.50 and $24.25 \%$ increase in yield over untreated control, respectively (Table 4). The oils were moderately effective in reducing thrips population in the mung bean flowers at $0.3 \%$ without any phytotoxicity. In a similar study, Egho and Emosairue (2010b) reported effective control of $M$. sjostedti on cowpea in Nigeria, using mineral oils. Dhaliwal (2018) evaluated the efficacy of several horticultural mineral oils against the thrips and mites on kinnow at Ludhiana, Punjab, and all the HMOs reduced the thrips population marginally providing about $40 \%$ control of thrips up to 7DAT. Phytotoxicity at concentrations more than $2 \%$, even though at higher concentrations, were more effective. Similarly, HMO at $1.5 \%$ reduced citrus fruit blemishes caused by mites and thrips in Pakistan (Khalid et al. 2012). In the present study, concentrations greater than $0.3 \%$ resulted in phytotoxicity on leaves. Phytotoxicity at such low concentrations could also be related to the hot and dry weather conditions prevailing in the cropping season at the time.

Comparative economics of different treatments evaluated against bean thrips over untreated control is presented in Table 5. The total cost for various treatments ranged from INR 1225 to INR 2300 per ha, while in insecticidal treatment, it was 818.50 INR per ha. The net returns over untreated control of different treatments ranged from INR 4865 to INR 32431.5 (69 to 460 USD) per ha. Maximum returns were obtained using dimethoate due to the highest efficacy and the lowest cost. Among the botanicals and HMOs evaluated, treatment with $10 \mathrm{ml} \mathrm{l}^{-1}$ of Nimbecidine $300 \mathrm{ppm}$ gave the highest net returns over untreated control, followed by $10 \mathrm{ml} \mathrm{l}^{-1}$ of Neem Kavach $1500 \mathrm{ppm}$ and NSKE at $5 \%$. If the farmers can collect and process the neem seed kernels themselves, it may further reduce the cost of treatment to get high returns.

\section{Conclusions}

For managing bean thrips in mung bean, dimethoate $30 \% \mathrm{EC}$ was found to be the most effective providing the maximum grain yield and the highest net returns over untreated control. Among all botanicals evaluated, 5\% spray of NSKE showed promising results.

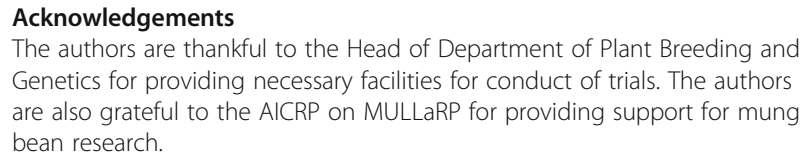

The authors are thankful to the Head of Department of Plant Breeding and Genetics for providing necessary facilities for conduct of trials. The authors are also grateful to the AICRP on MULLaRP for providing support for mung bean research.

\section{Authors' contributions}

HKC and RS contributed to the conceptualization of idea and planning of trials; $\mathrm{HS}$ and HKC contributed in conducting the trial in the field and data recording. RS contributed to the support in conduct of research trial. HS and HKC wrote the manuscript. All authors read and approved the final manuscript.

\section{Funding}

None

Availability of data and materials

The available data is included in the present manuscript.

Ethics approval and consent to participate

Not applicable

\section{Consent for publication}

Not applicable

\section{Competing interests}

The authors declare that they have no competing interests.

\section{Author details}

'Department of Entomology, Punjab Agricultural University, Ludhiana, Punjab 141004, India. ${ }^{2}$ Department of Plant Breeding and Genetics, Punjab

Agricultural University, Ludhiana, Punjab 141004, India.

Received: 19 June 2020 Accepted: 14 September 2020

Published online: 06 October 2020

\section{References}

Anonymous (2017) Package of practices for crops of Punjab Rabi 2017-18. Punjab Agricultural University, Ludhiana, pp 34-37

Asif MU, Muhammad R, Akbar W, Sohail M, Tariq JA, Ismail M (2018) Comparative efficacy of neem derivatives and imidacloprid against some cotton pests. J Entomol Zool Stud 6(3):113-117

Begum N, Sharma B, Pandey RS (2013) Calotropis procera and Anona squamosa: potential alternatives to chemical pesticides. British J Appl Sci Technol 3(2): 254-267

Chhabra KS, Kooner BS (1985a) Losses in summer mung bean due to insect pest in Punjab. Indian J Entomol 47:103-105

Chhabra KS, Kooner BS (1985b) Problem of flower shedding caused by thrips, Megalurothrips distalis on summer mung bean, Vigna radiata (L.) Wilczek, and its control. J Tropic Pest Manag 31:186-188

Dahiya PK, Linnemann AR, Boekel MAJS, Khetarpaul N, Grewal RB, Nout MJR (2013) Mung bean: technological and nutritional potential. Crit Rev Food Sci Nutr 55:670-688

Dhaliwal RS (2018) Biological activity of horticultural mineral oils against thrips and mites on Kinnow. Punjab Agricultural University, Ludhiana, MSc Thesis

Egho EO, Emosairue SO (2010a) Effect of neem seed extract on major pests of cowpea [Vigna unguiculata (L.) Walp] and influence on yield under calendar and monitored sprays. Ann Biol Res 1(2):210-220

Egho EO, Emosairue SO (2010b) Field evaluation of mineral oils for insect pests management and yield of cowpea (Vigna unguiculata (L.) Walp) in Abraka, Southern Nigeria. Arch Appl Sci Res 2:57-67

Gomez AK, Gomez AA (1984) Statistical procedure for agricultural research, 2nd edn. Wiley, New York, pp 207-215 
Henderson CF, Tilton EW (1955) Tests with acaricides against the brown wheat mite. J Econ Entomol 48(2):157-161

Irulandi S, Balasubramanian G (2000) Report on the effect of botanicals against Megalurothrips distalis (Thripidae: Thysanoptera) and Lampides boeticus (L.) (Lycaenidae: Lepidoptera) on greengram. J Insect Environ 5:175-176

Isman M, Koul O, Arnason J, Stewart J, Salloum G (1991) Developing a neembased insecticide for Canada. Mem Entomol Soc Can 123:39-46. https://doi. org/10.4039/entm123159039-1

Khalid MS, Malik AU, Saleem BA, Khan AS, Javed N (2012) Horticultural mineral oil application and tree canopy management improve cosmetic fruit quality of Kinnow mandarin. Afr J Agric Res 7(23):3464-3472. https://doi.org/10.5897/ AJAR11.1583

Kooner BS, Cheema HK, Kaur R (2006) Insect pests and their management. In: Shiv K (ed) Ali M. Advances in mung bean and urdbean. Indian Institute of Pulses Research, Kanpur, pp 335-401

Kooner BS, Chhabra KS, Sekhon HS, Dhingra KK, Cheema HS (1983) A new deformity in summer mung bean, Vigna radiata (L.) Wilczek. Pulse Newsl 3 : 40-42

Kordy AM, Barakat AST (2014) Efficiency of insecticides for controlling thrips insects (Thrips tabaci L.) infesting onion plants (Allium cepa L.) in Egypt. J Agric Res 3:586-591

Mensah RK, Frerot B, Al Dafel F (2005a) Effect of petroleum spray oils on oviposition behaviour and larval survival of Helicoverpa armigera and Ostrinia nubilalis. Int J Pest Manag 51:111-119

Mensah RK, Liang W, Gibbs D, Coates R, Johnson D (2005b) Evaluation of nC27 petroleum spray oil for activity against Helicoverpa spp. on commercial cotton fields in Australia. Int J Pest Manag 51:63-70

Morgan ED (2009) Azadirachtin, a scientific gold mine. Bioorg Med Chem 17: 4096-4105

Najar-Rodriguez AJ, Walter GH, Mensah RK (2007) The efficacy of a petroleum spray oil against Aphis gossypii glover on cotton. Part 1: Mortality rates and sources of variation. Pest Manag Sci 63:586-595

Regnault-Roger C, Philogène BJR (2008) Past and current prospects for the use of botanicals and plant allelochemicals in integrated pest management. Pharm Biol 46(1-2):41-52. https://doi.org/10.1080/13880200701729794

Singh DK, Verma TC, Aswal S, Aswani G (2009) Effect of different botanical pesticides against Thrips tabaci on garlic crop. Asian Agrihist 18(1):57-61

Traore F, Waongo A, Drabo E, Yamkoulga M, Dabire-Binso C, Sanon A (2019) Effects of neem (Azadirachta indica L.) oils spraying periods on the populations of Megalurothrips sjostedti Trybom and Maruca vitrata Fabricius in the cowpea field. Int J Biol Chem Sci 13(3):1300-1307

Verma AN, Singh HV, Khurana AD (1980) Record of some thrips of Hisar (Haryana). Haryana Agric Univ J Res 10:410-412

Vijayalakshmi PS, Amirthaveni S, Devadas RP, Weinberger K, Tsou SCS, Shanmugasundaram S (2003) Enhanced bioavailability of iron from mung bean and its effects on health of school children. Technical Bulletin No. 20 AVRDC Publication 03-559. The World Vegetable Center (AVRDC), Shanhua

Weinberger K (2003) Impact analysis of mung bean research in south and southeast Asia. Final report of GTZ Project No. 99.9117.5. The World Vegetable Center (AVRDC), Shanhua

\section{Publisher's Note}

Springer Nature remains neutral with regard to jurisdictional claims in published maps and institutional affiliations.

\section{Submit your manuscript to a SpringerOpen ${ }^{\circ}$ journal and benefit from:}

- Convenient online submission

- Rigorous peer review

- Open access: articles freely available online

- High visibility within the field

- Retaining the copyright to your article

Submit your next manuscript at $\boldsymbol{\nabla}$ springeropen.com 